\title{
Recurrent Plasma Cell Myeloma
}

National Cancer Institute

\section{Source}

National Cancer Institute. Recurrent Plasma Cell Myeloma. NCI Thesaurus. Code C7025.

The reemergence of plasma cell myeloma after a period of remission. 